\title{
PARADOXES OF CREATIVITY
}

\begin{abstract}
Accounts of the creative process tend to be retrospective and implicitly ground the creative act within the person, the mind, the moment, the idea; in doing so, they often miss the larger sociomaterial qualities that can provide us with important insights about the social relationality and playfulness of the creative process. In this article, we examine the creative process through an antenarrative lens that we consider very useful for theorizing the creative process from a cultural and sociomaterial perspective. More specifically, we argue that 'having an idea' is a contextualized and embodied process that can be regarded as an antenarrative of the overall creative process. We also discuss how the paradoxical relation between the formative and sudden manifestations of the creative act can be understood through the notion of play.
\end{abstract}

Keywords: sociomateriality; antenarrative; creative process; idea; play 


\section{PARADOXES OF CREATIVITY}

Paradoxes of creativity: examining the creative process through an antenarrative lens

\section{Introduction}

Having an idea is an essential act of creativity. It is, in the end, an embodied experience, a sojourn in not only the social but also in the materiality aspect of creativity. It is not simply cognitive, a lit lightbulb of the mind when searching for a fitting metaphor of creativity (Glăveanu, 2011). While helping us materialize the ephemeral and the illusive, the usual stories of 'having an idea' are often post-factum reconstructions and re-organizations of a much more complex, messy, embodied, and non-linear process, letting the creative process frequently appear superficial and naive. That is, retrospective stories of creativity tend to implicitly ground the creative process within the person, the mind, the moment, the idea, and often miss its larger sociomaterial qualities that can provide us with important insights about the social relationality and playfulness of the creative process. And, as we will argue here, while retrospective stories of creativity cannot be told without reference to people, minds and ideas, they should not be limited to them. Moreover, although we talk and think about creative processes in terms of stories, and stories by definition organize, usually along (linear) temporal lines, elements of our remembered experience, this should not make us blind to the fact that there is much more to the creative process than its social story. Or rather, anticipating our argument, there are ways to embed this story and make sense of it through its sociomaterial practices by embracing "the constitutive entanglement of the social and the material" (Orlikowski, 2007, p. 1439), thereby tapping into a much wider, dynamic, paradoxical, playful type of 'story' than we usually tell or hear about creativity and creators.

In this article, we start by discussing the epistemological and ontological implications of conceptualising creativity from a sociomaterial perspective. Second, we propose what seems to us a vital notion to understand the creative process and in particular the phase of 'having an idea': the concept of antenarrative (Boje, 2001, 2008, 2011, 2014). Third, we 


\section{PARADOXES OF CREATIVITY}

outline a conception of antenarratives and their different facets and manifestations that we believe is useful for theorizing the creative process from a cultural and sociomaterial perspective. In the end, we return to the experience of having an idea and discuss two of its manifestations - one formative, the other sudden - and the ways in which the paradoxical relation between them can be understood through the notion of play.

\section{Creativity in and in-between people}

Creative ideas, whether the result of an individual or team effort, are often assumed to originate from what Runco (1996) calls 'personal creativity', which is often (at least implicitly) described as an asocial, individualistic process. In order to understand personal creativity, scholars have focused either on the personality and socio-contextual aspects of creativity or on the cognitive, affective and conative processes 'upstream' (Howkins, 2005; Sacramento, Dawson, \& West, 2008). Whilst this focal separation brought important insights for our understanding of creativity in people, it caused and continues to cause problems when trying to understand creativity in-between people.

From a cognitive perspective, creativity in-between people has been associated with shared internal frames of reference (Mitchell, 1986), negotiated belief structures (Walsh, Henderson, \& Deighton, 1988), team mental models (Klimoski \& Mohammed, 1994), and team member schema similarity (Rentsch \& Hall, 1994), to name just a few. The latter approach received considerable interest in the academic world due to Rentsch and Klimoski's (2001) nuanced view of team cognition. The authors argue that member schemas are similar rather than shared, because cognitive schemas reside in the individual and thus cannot be identical. In other words, team member schemas can be conceptualized as interconnected knowledge bundles (Lord \& Maher, 1991) that are "characterized by incomplete agreement" (Rentsch \& Klimoski, 2001, p. 108), but help team members to organise and understand phenomena (Poole, Gray, \& Gioia, 1990). 


\section{PARADOXES OF CREATIVITY}

However, we argue that the creative process is more than a pure exercise of a single mind, something beyond sensory forms of understanding, a being in-between the sociomaterial entanglements inherent in creative work. This does not exclude that occasionally creativity happens as a pure mental exercise, but depending on the discipline and/or problem at hand, creativity emerges from playing with materials and acts of social relationality. For instance, in mathematics, it may be more common that creativity is solely an act of the mind, but even there the social entanglements will be at work. In contrast, in haute cuisine the sensory aspects, and thus the materiality of the context, are essential (Stierand, 2015), for it is a materiality of not seeing with the eyes, but seeing by touching, smelling, hearing and tasting the ingredients often through the use of tools, which then become extensions of the chef's body (see Dörfler \& Ackermann, 2012). Therefore, we assert that there is a phenomenological quality inherent in the creative process consisting of qualia, individual instances of subjective experience that cannot be put precisely into words or reduced to impersonal and objective features (Jackson, 1982; Lewis, 1929; Stierand \& Dörfler, 2014). Ontologically, this means that a sociomaterial conceptualisation of creativity cannot assume that human beings and things (social and material) exist as separate selfcontained entities, but that they exist as inseparable intra-acting "components" (Barad, 2003, p. 815):

"Relationships are not just the interactions of what was originally nonrelational; relationships are relational 'all the way down.' Things are not first self-contained entities and then interactive. Each thing, including each person, is first and always a nexus of relations [...] all things, including all practices, have a shared being and a mutual constitution in this sense. They start out and forever remain in relationship.” (Slife, 2004, p. 159) 


\section{PARADOXES OF CREATIVITY}

Consequently, in order to epistemologically capture creativity as a sociomaterial phenomenon, we must go in-between the material and "relational interactions and patternings that are recursively intimated in the fluxing and transforming of our lifeworlds" (Chia, 1995, pp. 581-582). This inevitably demands an intellectual quietness so that we can immerse ourselves in the sociomaterial phenomena unfolding around us and turn our attention to the sensual as well as mental experiences of the microprocesses of creativity (Dörfler, Stierand, \& Zizka, 2017).

\section{'Having an idea' as an antenarrative}

Building on the previously described ontological and epistemological basis, we view acts of creativity (processual components of the overall creative process) as relational processes that move in-between the intra- and inter-personal (Dinh et al., 2014; Glăveanu, 2014; Mainemelis, Kark, \& Epitropaki, 2015) relations of actors that inter-subjectively share the embodied and often atheoretical (Chia, 2003) and 'unspoken and unspeakable' aspects of creative work (Stierand, 2015; Stierand \& Dörfler, 2016). These relational processes are essentially entanglements of the social and material (Barad, 2003; Hultin \& Mähring, 2017) aspects of creativity that tell a story. That is, it is not just people that are storytellers, the 'land' in which creative work is produced, the tools, the artefacts and so on, all tell a story.

These sociomaterial stories of creativity, however, are never ready-made, wellbehaved stories waiting to be told from beginning to end, to be cultivated as neat narratives of creative action and repeatedly 'rehearsed' with others. Such neat narratives are as much inferred from the creative outcome as recalled from the creative process. On the contrary, the story of creativity 'as it takes place' in the sociomaterial world would naturally be messy, complex, non-linear and often impossible to capture on a temporal line, because of the unpredictability of the whats and hows of 'having an idea' - the rest of the creative process (e.g. judging and reworking the idea) seems to be significantly better behaved. Thus, we 


\section{PARADOXES OF CREATIVITY}

intend to capture the processual component of 'having an idea' by adopting Boje's conceptualization of antenarratives:

"Antenarrative is the fragmented, non-linear, incoherent, collective, unplotted and pre-narrative speculation, a bet. To traditional narrative methods antenarrative is an improper storytelling, a wager that a proper narrative can be constituted.” (Boje, 2000, n.a.)

We see Boje's description as fully compatible with our view of 'having an idea'. Antenarrative is a relational process that potentially will make futural sense and eventually lead to a retrospective narrative collapsed into beginning, middle and ending (Boje, 2008). In the context of creativity, we see antenarrative processes as pre-reflexive and embodied, bringing order to the messiness of 'having an idea'. They are the antecedents before and anticipatory preparation processes towards something new, something that is becoming; they are 'in the middle' and 'in-between' (Boje, 2001, p. 293), refusing to attach linear beginning, middle and ending (Boje, 2008, p. 28). As the antenarrative processes develop into a narrative, we make the step from 'having an idea' to the overall creative process. We further argue that the key strength of the relational process view is that the starting point of the authentic Being-ness of the dynamic historicality of the creative process is not viewed as something static, a 'structure' in the traditional sense of the term, but rather, as the beginning of multiple antenarrative processes, a constellation that somehow evolved and continues to evolve during creative work, eventually (but not always) becoming orderly story and narrative. Hence, while the antenarrative of 'having an idea' may evolve into various fully formed narratives (and thus different creative outcomes), or may never get there at all, we may go back from time to time to the same antenarrative and develop it into a new fully formed narrative. This means, we need to look at the entire creative process as an antenarrative.. 


\section{PARADOXES OF CREATIVITY}

\section{The creative process as an antenarrative}

The creative process involves aspects of human activities that reflect "maturity and experience" as well as those "that are found in early childhood" (Runco, 1996, pp. 3-4). Having an idea can be over long time horizons (Boje, Haley, \& Saylors, 2016; Stierand, 2015) during which creative individuals must sustain a kind of 'innocence-in-experience' (Barron, 1995) when preparing for enacting the creative process. This antenarrative process is called fore-having (Boje, 2014; Boje, Svane, \& Gergerich, 2016; Heidegger, 1962: \#150). A simple but illustrative example are the actions that haute cuisine chefs take before they start creating a new dish: ovens are turned on, pans and pots are put on the stove to have them heated up, knives get sharpened and all sorts of equipment that can be imagined to be potentially needed ready at-hand, for instance a bowl of ice cubes, is assembled; these imaginations of the future, mobilizing the past and guiding the present, have been referred to by Cole (1996) as prolepsis.

This antenarrative process, like the following three, must be understood as naturally interactive and recurring, constantly changing and being changed by each other (Boje, Haley, et al., 2016). Taken together, however, we suggest that they can form a relational process of creativity, starting with fore-having, followed by fore-structure, fore-telling and foreconception. The process of fore-structure is a going between the body of established narratives of past ideas and the current process of having an idea in order to establish awareness of the idea's social relationality and the materiality of the creative process as it emerges (Boje, Haley, et al., 2016; Boje, Svane, Henderson, \& Strevel, 2015; Heidegger, 1962: \#153). In other words, this 'idea fore-structure' can be understood as a mind-sensory practice towards achieving intuitive insight (Dörfler \& Ackermann, 2012), the act by which sociomaterial "elements of the respective domain knowledge are tacitly synthesized in a new way creating a novum" (Stierand \& Dörfler, 2016, p. 179). By "working out these forestructures" (Heidegger, 1962, section \#150), it is possible to sketch the idea's future 'Being- 


\section{PARADOXES OF CREATIVITY}

in-the-world' that is the expected chances the idea has to become an innovation, a new value that once will be part of the traditional domain knowledge.

Then, an antenarrative process of fore-telling starts that is a bet on the future through prospective sensemaking (Boje, Haley, et al., 2016; Boje et al., 2015; Heidegger, 1962: \#150). It is essentially the phase of moving forward the 'unspoken and unspeakable' elements of the intuitive insight about the idea, a phase of evaluation by intuitive judgment (Dörfler \& Ackermann, 2012; Stierand \& Dörfler, 2016). This evaluation shows, in our view, resemblance to Weick's process of disciplined imagination in theorizing, which, he argues, is far less rigid and linear than propagated and actually far more "intuitive, blind, wasteful, serendipitous, [and] creative" (Weick, 1989, p. 519). It is an evolutionary process of designing, conducting, and interpreting imaginary experiments (Weick, 1989) to foresee the becoming of the idea without ever quite getting there (Boje, Rosile, Durant, \& Luhman, 2004, p. 756).

Now, an antenarrative process of fore-conception starts to align the idea with the established narratives of past ideas through establishing a new language for the idea to be communicated, new symbols, and new practices of enactments. In short: new conceptions of sociomaterialities. This process aims to make sense of what is as yet not an orderly narrative of a creative idea (Boje, Haley, et al., 2016; Boje et al., 2015; Heidegger, 1962: \#150).

According to Boje's concept of antenarrative, the gravitational point that connects and brings all of the above antenarrative processes into interplay, eventually leading to a new idea, is called fore-caring, an affectionate concern for the future of the idea that is yet to arrive (Boje, 2014; Boje, Svane, et al., 2016):

"[H]ow we feel affection to the possible futures and relate to some futures as more attractive than others, and how we thus, in anticipation of the arrival of 


\section{PARADOXES OF CREATIVITY}

this future, resolutely act to pave the way for its actual arrival.” (Boje et al., 2015, p. 12)

\section{Connecting the dots through play}

In essence, we argue that paving the way for the creative process to unfold into the future through fore-caring can be fostered and maintained through play by bringing together the sociomateriality of actions, objects, people, and meaning with the aim to create (more) order (see Mainemelis \& Dionysiou, 2015; Mainemelis \& Ronson, 2006) - that is, to make the move from the antenarrative of the creative process to the fully formed narrative of the creative outcome.

The notion of antenarrative process of fore-caring connects the often opposing views of the creative act as being of a more formative nature or the result of sudden inspiration, of being intrinsically messy or, on the contrary, organized into what takes place before and after 'having the idea'.

Formative approaches understand the creative process as a search for new ideas by producing them in-between the senses and the mind through acts of encounter (Gherardi \& Perrotta, 2014, p. 143). Artisans, for example, often start with a vague and blurred vision of what they want to create and only during the process of production, when they start playing with the "materials, tools, techniques, design, form, and function", the vision that essentially inspired them becomes more and more clear (Guthrie, 2007, p. 2). In other words, through formation, artisans start to understand their antenarrative bet on the future by playing in an engaging manner (Mainemelis \& Ronson, 2006). This is visible in any form of craftsmanship which, far from being mechanical or repetitive, requires imagination, anticipation as well as skill (Glăveanu, in press; Sennett, 2008; Stierand, 2015). Approaches that acknowledge the notion of sudden inspiration argue that 'having an idea' is a "manifest sign of long, unconscious prior work" (Poincaré in Hadamard, 1996, p. 14), or what appears, at least from 


\section{PARADOXES OF CREATIVITY}

the outside, as a more asocial and individualistic antenarrative fore-structuring. The experience of getting the idea out of 'thin air' is undeniably part of the narrative of creativity for many people, including people who get to be recognized as creative geniuses. And yet, we believe that this type of fore-structuring does not contradict or deny the previous one, more apparently social and developmental in nature. Indeed, studies of creative insight consistently show that big breakthroughs are always embedded within longer trajectories of participation, materialized in 'smaller', less noticeable insights or fore-sights (see also Cosmelli \& Preiss, 2014).

As such, the element of playful experimentation is inseparable from the creative process, for as messy or orderly as it appears. In experiences of sudden insights, of 'having the idea', play is often used as a means to divert from the actual creative work, affecting creativity more indirectly (Mainemelis \& Ronson, 2006). Play becomes here an integrative concept, the 'glue' holding together different antenarrative elements, building on ideas but also often refusing to have the (final) idea. Thus, play, whether practiced in an engaging or diverging manner, can relieve from the coercive rules and norms of behaving and thinking, for example in organizations (March, 1976), and can foster cognitive and behavioural flexibility (Amabile, 1996; Weick, 1979). It can help creative individuals to stay in the inbetween, to work out the antenarrative that starts to emerge and may eventually lead to an orderly narrative (Boje, 2008). 


\section{PARADOXES OF CREATIVITY}

\section{References}

Amabile, T. M. (1996). Creativity in context: Update to the social psychology of creativity. Boulder, CO: Westview Press.

Barad, K. (2003). Posthumanist performativity: Toward an understanding of how matter comes to matter. Signs: Journal of Women in Culture and Society, 28(3), 801-831.

Barron, F. (1995). No rootless flower: An ecology of creativity. Cresskill, NJ: Hampton Press.

Boje, D. (2000). Introduction to narrative methods. Narrative Methods for Organizational and Communication Research

Boje, D. (2001). Narrative methods for organizational and communication research. London: SAGE Publications.

Boje, D. (2008). Antenarrative. In R. Thorpe \& R. Holt (Eds.), The sage dictionary of qualitative management research (pp. 28-30). London, UK: SAGE.

Boje, D. (2011). Storytelling and the future of organizations: An antenarrative handbook. New York, NY: Routledge.

Boje, D. (2014). Storytelling organizational practices: Managing in the quantum age: Routledge.

Boje, D., Haley, U., \& Saylors, R. (2016). Antenarratives of organizational change: The microstoria of burger king's storytelling in space, time and strategic context. Human Relations, 69(2), 391-418. 


\section{PARADOXES OF CREATIVITY}

Boje, D., Rosile, G., Durant, R., \& Luhman, J. (2004). Enron spectacles: A critical dramaturgical analysis. Organization Studies, 25(5), 751-774. doi: $10.1177 / 0170840604042413$

Boje, D., Svane, M., \& Gergerich, E. (2016). Counternarrative and antenarrative inquiry in two cross-cultural contexts. European Journal of Cross-Cultural Competence and Management, 4(1), 55-84.

Boje, D., Svane, M., Henderson, T., \& Strevel, H. (2015). Critical corporate social responsibility in tamara-land: The role of tetranormalizing fractals. Book chapter for a Springer collection, Rodolphe Ocler (ed.).

Chia, R. (2003). From knowledge-creation to the perfecting of action: Tao, basho and pure experience as the ultimate ground of knowing. Human Relations, 56(8), 953-981.

Chia, R. C. H. (1995). From modern to postmodern organizational analysis. Organization Studies, 16(4), 579-604. doi: 10.1177/017084069501600406

Cole, M. (1996). Cultural psychology: A once and future discipline. Cambridge, MA: Harvard University Press.

Cosmelli, D., \& Preiss, D. D. (2014). On the temporality of creative insight: A psychological and phenomenological perspective. Frontiers in psychology, 5.

Dinh, J., Lord, R., Gardner, W., Meuser, J., Liden, R., \& Hu, J. (2014). Leadership theory and research in the new millennium: Current theoretical trends and changing perspectives. The Leadership Quarterly, 25(1), 36-62.

Dörfler, V., \& Ackermann, F. (2012). Understanding intuition: The case for two forms of intuition. Management Learning, 43(5), 545-564. 


\section{PARADOXES OF CREATIVITY}

Dörfler, V., Stierand, M., \& Zizka, L. (2017, 5-7 September). Studying reflecting on becoming: Some philosophical reference points. Paper presented at the British Academy of Management (BAM) Annual Conference, University of Warwick, UK.

Gherardi, S., \& Perrotta, M. (2014). Between the hand and the head: How things get done, and how in doing the ways of doing are discovered. Qualitative Research in Organizations and Management: An International Journal, 9(2), 134-150.

Glăveanu, V. P. (2011). Is the lightbulb still on?: Social representations of creativity in a western context. The International Journal of Creativity and Problem Solving, 21(1), 53-72.

Glăveanu, V. P. (2014). Distributed creativity: Thinking outside the box of the creative individual. Cham: Springer.

Glăveanu, V. P. (in press). Creativity in craft. In J. C. Kaufman, V. P. Glăveanu \& J. Baer (Eds.), The cambridge handbook of creativity in different domains. Cambridge: Cambridge University Press.

Guthrie, C. (2007). On learning the research craft: Memoirs of a journeyman researcher. Journal of Research Practice, 3(1), Article M1.

Hadamard, J. (1996). The mathematician's mind: The psychology of invention in the mathematical field: Princeton University Press.

Heidegger, M. (1962). Being and time (J. Macquarrie \& E. Robinson, Trans.). Oxford: Blackwell.

Howkins, J. (2005). The mayor's commission on the creative industries. In J. Hartley (Ed.), The creative industries (pp. 117-125). Oxford: Blackwell. 


\section{PARADOXES OF CREATIVITY}

Hultin, L., \& Mähring, M. (2017). How practice makes sense in healthcare operations: Studying sensemaking as performative, material-discursive practice. Human Relations, 70(5), 566-593.

Jackson, F. (1982). Epiphenomenal qualia. The Philosophical Quarterly, 32(127), 127-136. doi: $10.2307 / 2960077$

Klimoski, R., \& Mohammed, S. (1994). Team mental model: Construct or metaphor? Journal of Management, 20(2), 403-437.

Lewis, C. I. (1929). Mind and the world order: Outline of a theory of knowledge. New York, NY: Charles Scribner's Sons.

Lord, R., \& Maher, K. (1991). Cognitive theory in industrial and organizational psychology. In M. Dunnette \& L. Hough (Eds.), Handbook of industrial and organizational psychology (2nd ed., Vol. 2, pp. 1-62). Palo Alto, CA: Consulting Psychologists Press.

Mainemelis, C., \& Dionysiou, D. (2015). Play, flow, and timelessness. In C. Shalley, M. Hitt \& J. Zhou (Eds.), The oxford handbook of creativity, innovation, and entrepreneurship (pp. 121-140). New York, NY: Oxford University Press.

Mainemelis, C., Kark, R., \& Epitropaki, O. (2015). Creative leadership: A multi-context conceptualization. Academy of Management Annals, 9(1), 393-482.

Mainemelis, C., \& Ronson, S. (2006). Ideas are born in fields of play: Towards a theory of play and creativity in organizational settings. Research in Organizational Behavior, $27,81-131$.

March, J. (1976). The technology of foolishness. In J. March \& J. Olsen (Eds.), Ambiguity and choice in organizations (pp. 69-81). Bergen: Universitetsforlaget. 


\section{PARADOXES OF CREATIVITY}

Mitchell, R. (1986). Team building by disclosure of internal frames of reference. The Journal of Applied Behavioral Science, 22(1), 15-28.

Orlikowski, W. J. (2007). Sociomaterial practices: Exploring technology at work. Organization Studies, 28(9), 1435-1448.

Poole, P., Gray, B., \& Gioia, D. (1990). Organizational script development through interactive accommodation. Group \& Organization Management, 15(2), 212-232.

Rentsch, J., \& Hall, R. (1994). Members of great teams think alike: A model of team effectiveness and schema similarity among team members. In M. Beyerlein \& D. Johnson (Eds.), Advances in interdisciplinary studies of work teams, vol. 1. Series on self-managed work teams (pp. 223-262). Greenwich, CT: JAI Press.

Rentsch, J., \& Klimoski, R. (2001). Why do 'great minds' think alike?: Antecedents of team member schema agreement. Journal of Organizational Behavior, 22(2), 107-120.

Runco, M. A. (1996). Personal creativity: Definition and developmental issues. New Directions for Child and Adolescent Development, 1996(72), 3-30. doi: $10.1002 / \mathrm{cd} .23219967203$

Sacramento, C., Dawson, J., \& West, M. (2008). Team creativity: More than the sum of its parts. Multi-level issues in creativity and innovation, Research in multi level issues series, 7, 269-287.

Sennett, R. (2008). The craftsman: Yale University Press.

Slife, B. D. (2004). Taking practice seriously: Toward a relational ontology. Journal of Theoretical and Philosophical Psychology, 24(2), 157-178. 


\section{PARADOXES OF CREATIVITY}

Stierand, M. (2015). Developing creativity in practice: Explorations with world-renowned chefs. Management Learning, 46(5), 598-617.

Stierand, M., \& Dörfler, V. (2014). Researching intuition in personal creativity. In M. Sinclair (Ed.), Handbook of research methods on intuition (pp. 249-263). Cheltenham: Edward Elgar.

Stierand, M., \& Dörfler, V. (2016). The role of intuition in the creative process of expert chefs. Journal of Creative Behavior, 50(3), 178-185.

Walsh, J., Henderson, C., \& Deighton, J. (1988). Negotiated belief structures and decision performance: An empirical investigation. Organizational Behavior and Human Decision Processes, 42(2), 194-216.

Weick, K. (1979). The social psychology of of organizing. Reading, MA: Addison-Wesley. 